\title{
Mutation of the Tobacco Mosaic Tobamovirus 126- and 183-kDa Proteins: Effects on Phloem-Dependent Virus Accumulation and Synthesis of Viral Proteins
}

\author{
Peter M. Derrick, Shelly A. Carter, and Richard S. Nelson \\ The Samuel Roberts Noble Foundation Inc., 2510 Sam Noble Parkway, Ardmore, OK 73401, U.S.A. \\ Received 5 November 1996. Accepted 28 March 1997.
}

\begin{abstract}
The masked and U1 strains of tobacco mosaic tobamovirus differ in symptom phenotype and in phloem-dependent accumulation in tobacco. The symptom phenotype is determined by eight amino acids in the 126- and 183-kDa proteins that differ between the two strains. In this study, slow phloem-dependent accumulation of the masked strain was shown to be determined by these same eight amino acids, but some symptomatically severe mutants altered at specific positions within the eight amino acids were inefficient in phloem-dependent accumulation. Therefore, the appearance of severe symptoms does not require rapid phloem-dependent accumulation. There was no consistent relationship between the accumulation of virus coat protein, movement protein, or 126- and 183-kDa protein in inoculated protoplasts and the efficiency of phloem-dependent accumulation in stem tissue. Therefore, the difference in phloem-dependent accumulation between the masked strain, its mutants, and the $U 1$ strain in most instances resulted from the functional competence of the 126- and/or 183-kDa proteins or a host response to their change and not from their quantities or the quantities or functional competence of the movement proteins or coat proteins.
\end{abstract}

Additional keywords: long-distance movement, replicase, symptom determinants, systemic infection.

The tobacco mosaic virus (TMV) genome codes for at least four proteins in infected plants. Two of these virus-encoded proteins, the movement protein (MP) and the coat protein (CP), interact with viral RNA and with components of the host plant to accomplish movement between cells and to distant organs (recent reviews include Carrington et al. 1996; Gilbertson and Lucas 1996; Séron and Haenni 1996). The 126$\mathrm{kDa}$ protein and $183-\mathrm{kDa}$ protein, translated by readthrough of the amber terminator of the $126-\mathrm{kDa}$ protein open reading frame (ORF), are both involved in viral replication. The 126$\mathrm{kDa}$ protein appears to modulate replication, but unlike the $183-\mathrm{kDa}$ protein, it is not absolutely required for this function (Ishikawa et al. 1986; Ishikawa et al. 1991). The 126-kDa protein ORF contains sequences similar to those of methyltransferases, and helicases in other viruses and nucleoside triphosphate binding consistent with RNA-dependent RNA polymerase or guanylyltransferase activities (Evans et al. 1985;

Corresponding author: R. S. Nelson; E-mail: rsnelson@ noble.org
Dunigan and Zaitlin 1990) have been detected in association with this protein.

We have been investigating the viral basis for the very different disease symptoms elicited by two strains of TMV on Nicotiana tabacum L., the symptomatically severe U1 strain (hereinafter referred to as U1) and the attenuated "masked" strain described by Holmes (1934). The masked strain causes a very mild chlorotic mottling of systemically infected leaves of tobacco. The region of the genome ultimately responsible for the masked symptom phenotype was identified as the 126$\mathrm{kDa}$ protein ORF (Holt et al. 1990). Within the 126-kDa protein ORF, there are 31 nucleotide differences between the progeny of the cloned masked strain (designated $\mathrm{M}^{\mathrm{IC}}$ ) and $\mathrm{U} 1$ (Goelet et al. 1982; Holt et al. 1990), eight of which result in eight amino acid differences between the 126- and $183-\mathrm{kDa}$ proteins of the two viruses (Fig. 1). Substitution of these eight nucleotides in the $126-\mathrm{kDa}$ protein ORF of $\mathrm{M}^{\mathrm{IC}}$ with those found at corresponding positions in the $\mathrm{U} 1$ sequence resulted in a progeny virus that induced symptoms as severe as those induced by U1 (Shintaku et al. 1996). That substitutions at the eight codon-determining nucleotides dramatically altered disease symptom formation suggested that the 126- and/or 183$\mathrm{kDa}$ proteins, rather than the viral nucleotide sequence or structure, were responsible for determining the symptom phenotypes of these viruses. This was proven experimentally by further mutation of the codons for amino acids 360 and 601 of the 126- and 183-kDa proteins (Bao et al. 1996). The eight amino acids that determine the masked strain symptom phenotype are located within a region of the $126-\mathrm{kDa}$ protein that is between sequence domains believed to have methyltransferase and helicase activities (Gorbalenya and Koonin 1989; Rozanov et al. 1992; Shintaku et al. 1996) (Fig. 1). The function of this portion of these proteins remains to be identified.

In addition to eliciting mild disease symptoms, the masked strain was delayed in phloem-dependent accumulation (Holmes 1934; Nelson et al. 1993). Virus-encoded proteins and all singlestranded viral RNA species of both U1 and the masked strain accumulated to similar levels in inoculated leaves and protoplasts of N. tabacum (Nelson et al. 1993). Within inoculated leaves, masked strain virus was detected in similar numbers of mesophyll and bundle sheath cells but in fewer phloem parenchyma and companion cells compared with the U1 strain (Ding et al. 1995). In young tissues invaded via the phloem, accumulation of masked strain viral products was delayed (Nelson et al. 1993). These studies addressed the phloem- 
dependent accumulation phenotype of the masked strain but did not map determinants of this phenotype on the viral genome. In this study, we used site-directed mutants to investigate the influence of the eight symptom-determining amino acids within the 126- and 183-kDa proteins on phloem-dependent accumulation of $N$. tabacum by $\mathrm{U} 1$ and $\mathrm{M}^{\mathrm{IC}}$. The involvement of the TMV MP and CP in this process was also analyzed.

\section{RESULTS}

\section{Mapping determinants of the slow phloem-dependent accumulation phenotype of $\mathrm{M}^{\mathrm{IC}}$.}

Phloem-dependent accumulation of the mutants of $\mathrm{M}^{\mathrm{IC}}$ described by Shintaku et al (1996) was analyzed in $N$. tabacum 'Xanthi nn' plants (systemic host) by tissue print immunoblotting to define nucleotides responsible for this phenotype. The nomenclature for the mutants used in this study and the disease symptoms they induce are described in Figure 1. Tissue prints of stems from plants inoculated with some of these mutants revealed substantial differences in the rate of phloem-dependent virus accumulation between 3 and 5 days
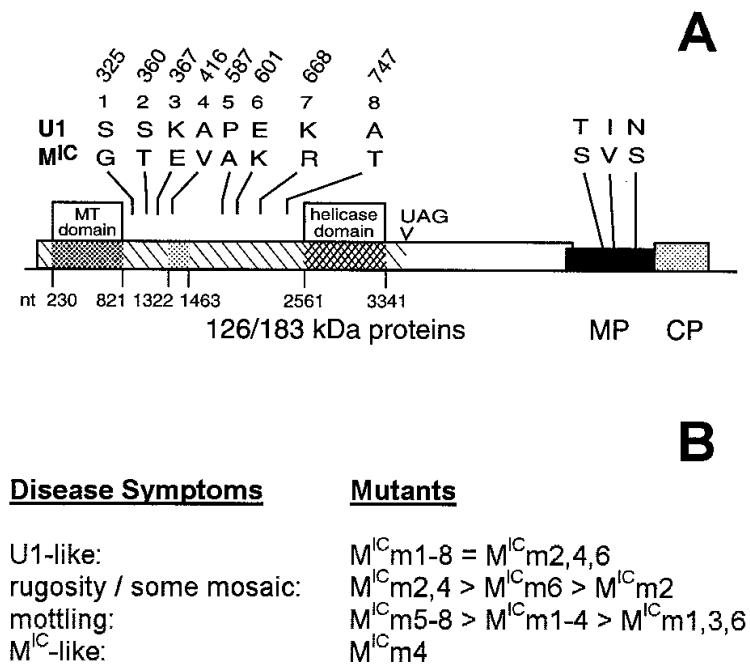

Fig. 1. Genome organization of tobacco mosaic virus (TMV), showing the amino acid differences between $\mathrm{M}^{\mathrm{IC}}$ - and $\mathrm{U} 1$-encoded proteins, their locations, and the different symptoms induced by various mutants of $\mathrm{M}^{\mathrm{IC}}$. A, Boxes represent open reading frames and horizontal lines untranslated sequences. $\mathrm{MP}=$ movement protein, and $\mathrm{CP}=$ coat protein. The position of the leaky stop codon (UAG) terminating the 126-kDa open reading frame is shown. Within the $126-\mathrm{kDa}$ open reading frame, the putative methyltransferase (MT) and helicase domains are shown as determined previously (Shintaku et al. 1996). Numbers below the diagram are positions of nucleotides (nt) relative to the $5^{\prime}$ terminus of the TMV leader (Goelet et al. 1982). The stippled region between nucleotides 1322 and 1463 is a region of sequence conservation between Sindbis-like viruses with unidentified function (Shintaku et al. 1996). Amino acid differences between $\mathrm{M}^{\mathrm{IC}}$ and $\mathrm{U} 1$ are shown in one-letter code. Positions numbered 1 to 8 are the arbitrary designations for those amino acids that differ between $\mathrm{M}^{\mathrm{IC}}$ and $\mathrm{U} 1$ in the $126-\mathrm{kDa}$ protein. Mutants of $\mathrm{M}^{\mathrm{IC}}$ were generated in which some or all of these amino acids were changed to those found in $\mathrm{U} 1$ at these positions. Oblique numbers show the positions of these amino acids relative to the $\mathrm{N}$ terminus of the $126-\mathrm{kDa}$ protein, exclusive of the initial methionine (Goelet et al. 1982). Nomenclature of mutants indicates mutated positions. For example, $\mathrm{M}^{\mathrm{IC}} \mathrm{m} 2,4$ is $\mathrm{M}^{\mathrm{IC}}$ with positions 2 and 4 changed to the corresponding U1 amino acids. B, Symptoms induced by mutants on Xanthi nn plants (Shintaku et al. 1996). postinoculation (dpi) (Fig. 2). $\mathrm{M}^{\mathrm{IC}} \mathrm{m} 4$ accumulated in stem tissue more slowly than any other virus. $\mathrm{M}^{\mathrm{IC}}, \mathrm{M}^{\mathrm{IC}} \mathrm{m} 2, \mathrm{M}^{\mathrm{IC}} \mathrm{m} 6$, $\mathrm{M}^{\mathrm{IC}} \mathrm{m} 2,4, \quad \mathrm{M}^{\mathrm{IC}} \mathrm{m} 1,3,6, \mathrm{M}^{\mathrm{IC}} \mathrm{m} 1-4$, and $\mathrm{M}^{\mathrm{IC}} \mathrm{m} 5-8$ accumulated slowly at rates that were similar but not identical. $\mathrm{M}^{\mathrm{IC}} \mathrm{m} 1-4$, $\mathrm{M}^{\mathrm{IC}} \mathrm{m} 2,4$, and $\mathrm{M}^{\mathrm{IC}} \mathrm{m} 5-8$ accumulated slightly faster than others in this group. $\mathrm{U} 1, \mathrm{M}^{\mathrm{IC}} \mathrm{m} 1-8$, and $\mathrm{M}^{\mathrm{IC}} \mathrm{m} 2,4,6$ accumulated with a similar efficiency that was greater than those of all other viruses. We were unable to alter the phloem-dependent accumulation phenotypes exhibited by $\mathrm{M}^{\mathrm{IC}}, \mathrm{U} 1$, and the sitedirected mutants by inoculating plants with greater amounts of the slowly invading viruses and smaller amounts of the rapidly invading viruses (data not shown).

\section{Measurement of accumulation of viral proteins in protoplasts.}

Because we had engineered alterations within the $126-\mathrm{kDa}$ protein, known to be required for efficient replication of the virus, we measured the rates of accumulation of viral products of several mutants in Xanthi nn protoplasts in which compromised viral movement functions should not alter virus accumulation.

Analysis of protoplast extracts by enzyme-linked immunosorbent assay (ELISA) revealed that the $\mathrm{CP}$ of $\mathrm{U} 1, \mathrm{M}^{\mathrm{IC}}$, and all tested mutants accumulated with similar kinetics over $42 \mathrm{~h}$ in Xanthi nn mesophyll protoplasts (Fig. 3), although mutant $\mathrm{M}^{\mathrm{IC}} \mathrm{m} 4$ accumulated more slowly and to lower levels of virus than $\mathrm{U} 1$ or $\mathrm{M}^{\mathrm{IC}}$ (Fig. 3B). Additional mutations at or around the eight substituted positions were not detected in the progeny of any of the mutants after multiplication in protoplasts, except for $\mathrm{M}^{\mathrm{IC}} \mathrm{m} 2,4$. The majority of the progeny of this isolate population had mutated to $\mathrm{M}^{\mathrm{IC}} \mathrm{m} 2,3,4$. We also monitored the accumulation of the $\mathrm{CP}$ of $\mathrm{U} 1, \mathrm{M}^{\mathrm{IC}}$, and the sitedirected mutants of $\mathrm{M}^{\mathrm{IC}}$ in the inoculated leaves of the plants utilized for tissue prints. There was no consistent positive relationship between the rate of $\mathrm{CP}$ accumulation in the inoculated leaves and that in the stems (data not shown).

Proteins synthesized in protoplasts were radiolabeled with ${ }^{35}[\mathrm{~S}]$-methionine and ${ }^{35}[\mathrm{~S}]$-cysteine from 8 to $10 \mathrm{~h}$ and 15 to $17 \mathrm{~h}$ postinoculation with viruses to monitor the amounts of radiolabel incorporated into the $183-$ and $126-\mathrm{kDa}$ proteins and the MP (Fig. 4). A protein corresponding to CP was not resolved (see also Fig. 5 in Ishikawa et al. 1991). The mean relative accumulation of the $126-\mathrm{kDa}$ protein from 8 to $10 \mathrm{~h}$ postinoculation was determined because this was reliably the most strongly labeled and distinct infection-specific band on autoradiographs (Fig. 4 and Table 1). Signal from the 126-kDa protein was approximately 2.4 -fold that from the $183-\mathrm{kDa}$ protein for U1, and similar values were obtained for the other viruses (Fig. 4 and data not shown). Statistically valid differences in the rate of incorporation of radiolabel into the 126$\mathrm{kDa}$ protein were observed only between $\mathrm{M}^{\mathrm{IC}} \mathrm{m} 4$ and the rest of the viruses and between $\mathrm{M}^{\mathrm{IC}} \mathrm{m} 6$ and the rest of the viruses tested (Table 1). A trend was apparent in that those viruses that accumulated the most $126-\mathrm{kDa}$ protein induced the most severe symptoms (compare Figure 1B with Table 1). However, a perfect positive correlation was not observed between the accumulation of $126-\mathrm{kDa}$ protein in protoplasts and systemic accumulation of virus (compare Figure 2 with Table 1).

${ }^{35} \mathrm{~S}$-labeled MP accumulated in amounts that were too low for accurate quantitation under the conditions used, but the levels of MP appeared to be similar for all the viruses, except $\mathrm{M}^{\mathrm{IC}} \mathrm{m} 4$ 
(Fig. 4), which accumulated less than other viruses. To determine the levels of MP during the early stages of infection of protoplasts, immunoblot analyses were performed (Fig. 5). Similar levels of MP were detected in extracts from protoplasts infected with $\mathrm{U} 1, \mathrm{M}^{\mathrm{IC}}$, and $\mathrm{M}^{\mathrm{IC}} \mathrm{m} 1-8$ at $3 \mathrm{~h}$ postinoculation and thereafter (Fig. 5). MP accumulation for mutants $\mathrm{M}^{\mathrm{IC}} \mathrm{m} 2$, $\mathrm{M}^{\mathrm{IC}} \mathrm{m} 4$, and $\mathrm{M}^{\mathrm{IC}} \mathrm{m} 6$ was delayed by approximately $2 \mathrm{~h}$ (Fig. 5). In these experiments, the antibody cross-reacted with one highabundance plant protein with an apparent molecular mass of approximately $32 \mathrm{kDa}$ (Fig. 5) (Deom et al. 1987) and several lower-abundance proteins. The major cross-reacting $N$. tabacum protein served as a useful internal standard to verify relative amounts of protoplasts applied to each lane for sodium dodecyl sulfate-polyacrylamide gel electrophoresis (SDS-PAGE).

\section{Virus accumulation in transgenic tobacco} expressing TMV MP.

To determine whether MP, supplied in trans, could alter the $\mathrm{M}^{\mathrm{IC}}$ phenotype, plants of transgenic $N$. tabacum line 277, which expresses the U1 MP (Deom et al. 1987), were inoculated with $\mathrm{M}^{\mathrm{IC}}$ and U1. Accumulation of $\mathrm{M}^{\mathrm{IC}}$ and U1 CPs in inoculated leaves and leaves infected by phloem-mediated invasion were unaltered by the presence of the transgenederived MP (Table 2). Disease symptoms induced by $\mathrm{M}^{\mathrm{IC}}$ and U1 on leaves infected by phloem-mediated invasion were also unaltered by the presence of transgenically expressed MP in line 277 plants (data not shown).

\section{DISCUSSION}

Shintaku et al. (1996) reported differences in disease symptom phenotypes among site-directed mutants of $\mathrm{M}^{\mathrm{IC}}$. We now report differences in rates of phloem-dependent accumulation displayed by these mutants in $N$. tabacum. $\mathrm{M}^{\mathrm{IC}} \mathrm{m} 1-8$, which is $\mathrm{M}^{\mathrm{IC}}$ genetically modified to encode U1-identical 126- and 183$\mathrm{kDa}$ proteins, accumulated at a rate similar to that of $\mathrm{U} 1$ in Xanthi nn stems (Fig. 2). $\mathrm{M}^{\mathrm{IC}} \mathrm{m} 1-8$ and U1 also induce indistinguishable symptoms on Xanthi nn (Shintaku et al. 1996). The most efficiently invading viruses $\left(\mathrm{U} 1, \mathrm{M}^{\mathrm{IC}} \mathrm{m} 2,4,6\right.$, and $\mathrm{M}^{\mathrm{IC}} \mathrm{m} 1-8$ ) (Fig. 2) are those that induce the most severe disease symptoms (Shintaku et al. 1996). Therefore, for $\mathrm{M}^{\mathrm{IC}} \mathrm{m} 1-8$ and $\mathrm{M}^{\mathrm{IC}} \mathrm{m} 2,4,6$, both phloem-dependent accumulation and

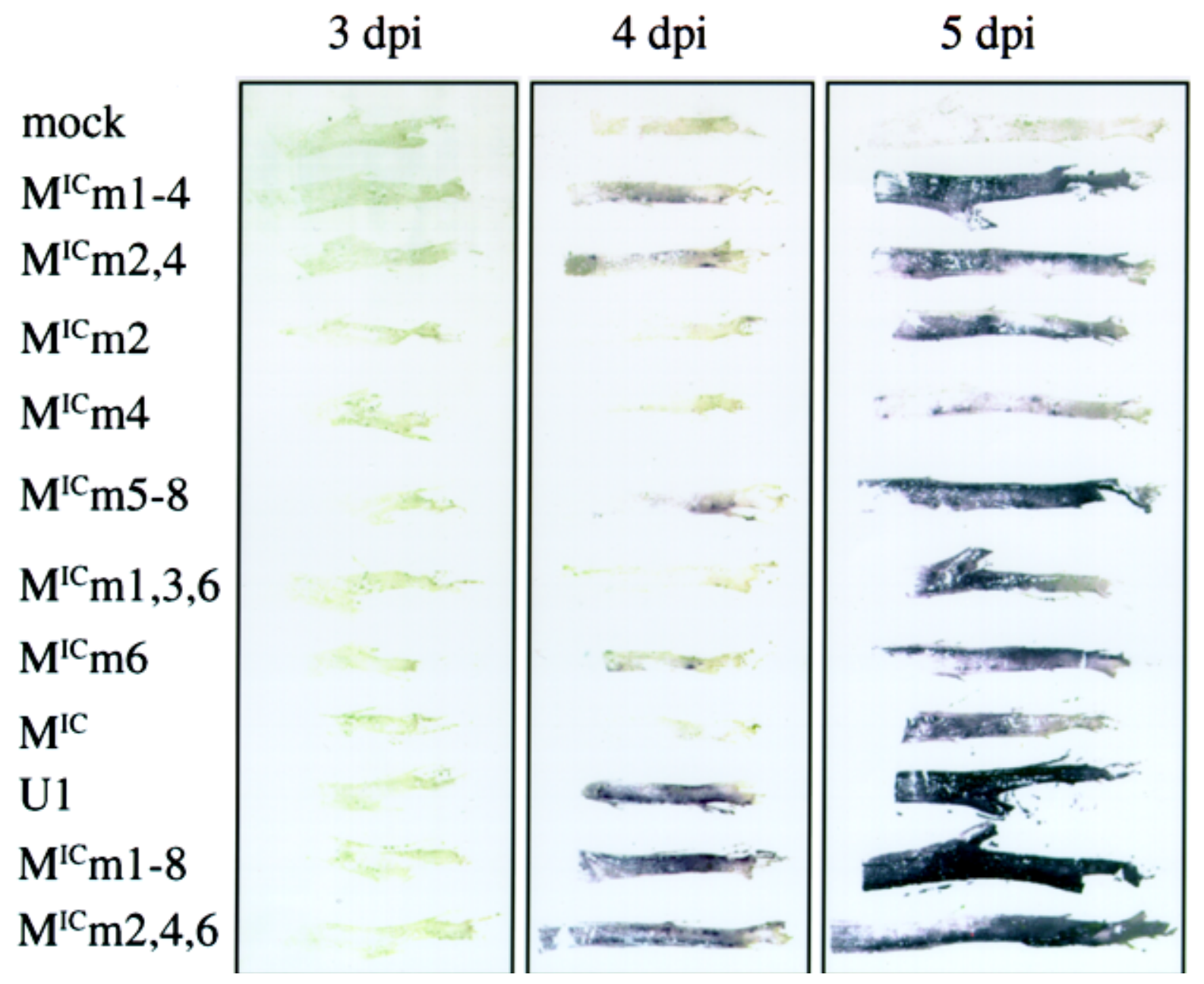

Fig. 2. Representative tissue print immunoblots showing accumulation of tobacco mosaic virus in tobacco stems at 3 , 4, and 5 days postinoculation (dpi). Images are prints of longitudinal sections through stems of Xanthi nn plants cut just above the position of the inoculated leaf (stem apices are at the right end of each print). Young Xanthi nn plants at similar growth stages were inoculated with approximately $0.25 \mu \mathrm{g}$ of virus per milliliter on the distal half of one leaf per plant. Infectivities of inocula were standardized and checked by inoculation onto a local-lesion host. Tests were conducted in triplicate in each of two separate experiments, and the results were similar. 
symptom severity were controlled by the same amino acid substitutions within the 126- and $183-\mathrm{kDa}$ proteins. For all mutants, however, there was not a perfect correlation between the rate of phloem-dependent accumulation (Fig. 2) and the severity of disease symptoms (Shintaku et al. 1996). For example, $\mathrm{M}^{\mathrm{IC}} \mathrm{m} 2$ and $\mathrm{M}^{\mathrm{IC}} \mathrm{m} 6$ displayed inefficient phloemdependent accumulation, with rates similar to that of $\mathrm{M}^{\mathrm{IC}}$, but induced severe symptoms. Thus, early phloem-dependent accumulation in stems is not necessary for severe symptom
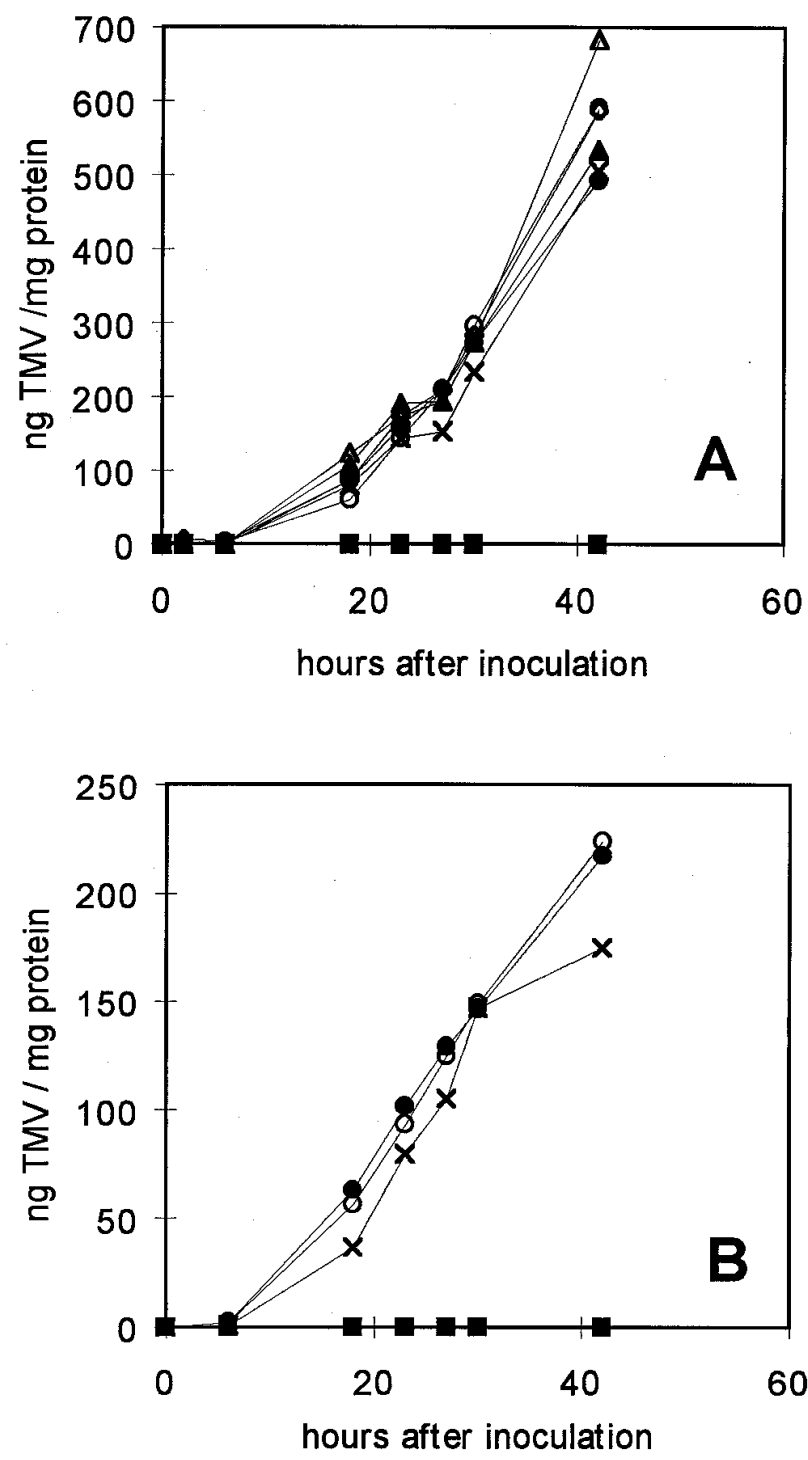

Fig. 3. Accumulation of virus in Xanthi nn protoplasts after inoculation with mutants, $\mathrm{M}^{\mathrm{IC}}$, and $\mathrm{U} 1$. Tobacco mosaic virus (TMV) coat protein accumulation was estimated by ELISA with extracts of protoplasts inoculated with $\mathbf{A}, \mathrm{M}^{\mathrm{IC}}, \bullet-\bullet ; \mathrm{U} 1,0-0 ; \mathrm{M}^{\mathrm{IC}} \mathrm{m} 2, \diamond-\diamond ; \mathrm{M}^{\mathrm{IC}} \mathrm{m} 6, \Delta-\Delta$; $\mathrm{M}^{\mathrm{IC}} \mathrm{m} 2,4, \mathbf{\Delta}-\mathbf{\Delta} ; \mathrm{M}^{\mathrm{IC}} \mathrm{m} 1,3,6, \times-\mathrm{x}$; or water, - and $\mathbf{B}, \mathrm{M}^{\mathrm{IC}}, \bullet-\bullet ;$ $\mathrm{U} 1,0-0 ; \mathrm{M}^{\mathrm{IC}} \mathrm{m} 4, \times-\mathrm{x}$; or water, $-\mathbf{\square}$. Data points are means of measurements from three separate experiments normalized with respect to percentage of protoplasts infected for each treatment (the proportion infected ranged from 40 to $95 \%$ ). Data in $\mathbf{A}$ and $\mathbf{B}$ are from different experiments. Differences in accumulation of coat protein of different viruses in $\mathbf{A}$ were not significant in a pooled analysis of variance. In $\mathbf{B}$, means for $\mathrm{M}^{\mathrm{IC}} \mathrm{m} 4$ were significantly different from those of $\mathrm{M}^{\mathrm{IC}}$ and $\mathrm{U} 1$ at the $5 \%$ level. induction, and amino acids in addition to those at positions 2 and 6 (e.g., position 4) are necessary for U1-like phloemdependent accumulation.

Mutation of residues in the $126-$ and $183-\mathrm{kDa}$ proteins had only a moderate effect on the accumulation of the $126-\mathrm{kDa}$ protein in protoplasts during in vivo labeling experiments. Only $\mathrm{M}^{\mathrm{IC}} \mathrm{m} 4$ accumulated significantly less $126-\mathrm{kDa}$ protein than the other viruses (Fig. 4 and Table 1). $\mathrm{M}^{\mathrm{IC}} \mathrm{m} 4$ was the only virus to accumulate more slowly than $\mathrm{M}^{\mathrm{IC}}$ in stem tissue (Fig. 2) and to accumulate less $\mathrm{CP}$ and MP in protoplasts
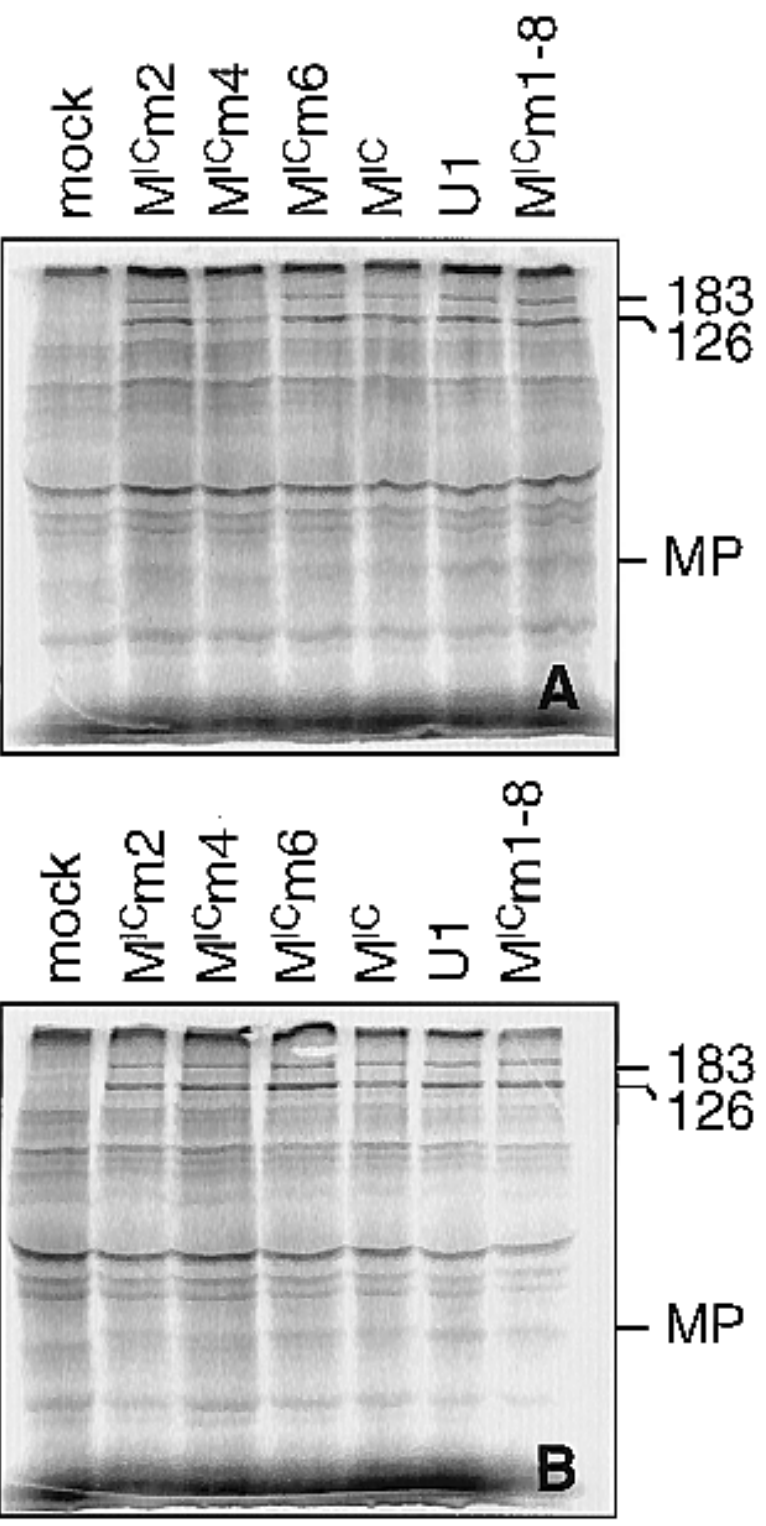

Fig. 4. Proteins synthesized in protoplasts between 8 and $10 \mathrm{~h}$ and 15 and $17 \mathrm{~h}$ postinoculation with tobacco mosaic virus (TMV) or water only. Protoplasts were inoculated with TMV or water (mock) and cultured at $24^{\circ} \mathrm{C}$ for $\mathbf{A}, 8 \mathrm{~h}$ or $\mathbf{B}, 15 \mathrm{~h}$ before they were labeled for $2 \mathrm{~h}$ with ${ }^{35}[\mathrm{~S}]$-methionine and ${ }^{35}[\mathrm{~S}]$-cysteine. Proteins were separated by sodium dodecyl sulfate-polyacrylamide gel electrophoresis, and radiolabeled proteins were detected with a Molecular Dynamics PhosphorImager. Positions of the viral 126- and 183-kDa proteins and movement proteins (MP) are indicated. The identity of the MP band was confirmed by immunoblotting (data not shown). 
(Figs. 3 and 5). This mutant therefore was debilitated in the production of all viral proteins, and its slow phloemdependent accumulation phenotype may be mostly the result of this defect. The converse accumulation of large amounts of $126-\mathrm{kDa}$ protein, however, did not ensure that a virus would show rapid phloem-dependent accumulation. $\mathrm{M}^{\mathrm{IC}} \mathrm{m} 6$ incorporated label into the $126-\mathrm{kDa}$ protein more efficiently than did $\mathrm{U} 1$, but it displayed an $\mathrm{M}^{\mathrm{IC}}$-like phloem-dependent accumulation phenotype. $\mathrm{M}^{\mathrm{IC}}, \mathrm{M}^{\mathrm{IC}} \mathrm{m} 2$, and $\mathrm{M}^{\mathrm{IC}} \mathrm{m} 1,3,6$, which accumulated slightly but not significantly less $126-\mathrm{kDa}$ protein than U1, did not accumulate as rapidly in stems as U1. In previous studies, we were also unable to detect by Western blot (immunoblot) a substantial difference between the parental masked strain and the U1 strain in the $126-\mathrm{kDa}$ protein accumulated in protoplasts (Nelson et al. 1993). The lack of a clear correlation between $126-\mathrm{kDa}$ protein accumulation in protoplasts and phloem-dependent accumulation suggests that the functional competence of this protein (and/or the $183-\mathrm{kDa}$ protein) rather than the rate of its synthesis controls the phloem-dependent accumulation phenotype. The functional competence of this protein could be compromised in several ways. Either the $126-\mathrm{kDa}$ proteins of $\mathrm{M}^{\mathrm{IC}}$ and its mutants are structurally altered and consequently inefficient in enzymatic or binding activities or a host response is limiting the capability of the $126-\mathrm{kDa}$ protein (and possibly other viral proteins) to carry out its (their) functions. The latter possibility has been suggested as a potential cause of disease symptom alteration with other mutant viruses (Goulden and Baulcombe 1993; Köhm et al. 1993; Scholthof et al. 1993; De Jong and Ahlquist 1995; Fenczik et al. 1995).

Because we were investigating a phenomenon that was a consequence of differences in viral replicase proteins and yet one that apparently influenced systemic virus movement, synthesis of the CP and MP by U1, M ${ }^{\mathrm{IC}}$, and several of our mutants was examined in detail. Previously, the accumulation of CP by $\mathrm{M}^{\mathrm{IC}}$ and U1 was shown to be similar in protoplasts (Nelson et al. 1993). In the current study, a similar result was obtained for all

Table 1. Relative incorporation of ${ }^{35}$ S-labeled amino acids into the 126$\mathrm{kDa}$ protein of tobacco mosaic virus variants in protoplasts

\begin{tabular}{lc}
\hline Virus & $\begin{array}{c}\text { Relative }{ }^{35} \mathbf{S} \\
\text { incorporation }\end{array}$ \\
\hline $\mathrm{M}^{\mathrm{IC}} \mathrm{m} 6$ & 1.29 \\
$\mathrm{U} 1$ & 1.00 \\
$\mathrm{M}^{\mathrm{I}} \mathrm{m} 1-8$ & 0.94 \\
$\mathrm{M}^{\mathrm{IC}} \mathrm{m} 2$ & $0.85^{\mathrm{z}}$ \\
$\mathrm{M}^{\mathrm{IC}} \mathrm{m} 1,3,6$ & 0.80 \\
$\mathrm{M}^{\mathrm{IC}}$ & 0.74 \\
$\mathrm{M}^{\mathrm{IC}} \mathrm{m} 4$ & 0.43 \\
\hline${ }^{\mathrm{x}}$ Protoplasts were inoculated with viral RNA and incubated for $2 \mathrm{~h}$ with \\
${ }^{35}[\mathrm{~S}]-$ methionine and ${ }^{35}[\mathrm{~S}]-c y s t e i n e$ at $8 \mathrm{~h}$ postinoculation. \\
${ }^{\mathrm{y}}$ Proteins were separated by sodium dodecyl sulfate-polyacrylamide gel \\
electrophoresis (SDS-PAGE), and dried gels were analyzed with a \\
Molecular Dynamics PhosphorImager and ImageQuant software. Data \\
were corrected to normalize differences in the percentage of proto- \\
plasts infected for each treatment and differences in protein loadings \\
on SDS-PAGE gels (estimated by quantitating a radiolabeled plant pro- \\
tein band). Values represent the number of counts (relative units) of ${ }^{35} \mathrm{~S}$ \\
incorporated into the 126-kDa protein per infected protoplast for each \\
virus relative to the value obtained for U1, which was adjusted to 1.00. \\
Values are means of data from four separate experiments. Least sig- \\
nificant difference ( $\alpha=0.05$ ) $=0.27$ in a two-way analysis of variance. \\
z Mean of data from three experiments.
\end{tabular}

the mutants of $\mathrm{M}^{\mathrm{IC}}$ except $\mathrm{M}^{\mathrm{IC}} \mathrm{m} 4$. Since the CPs of all viruses tested were identical and since, except for $\mathrm{M}^{\mathrm{IC}} \mathrm{m} 4$, all viruses accumulated $\mathrm{CP}$ to similar levels regardless of the rate of phloem-dependent accumulation, CP cannot have limited phloem-dependent accumulation of the mutant viruses.

MP accumulation was similar for U1 and the masked strain in crude cell wall extracts from inoculated leaves at 3 to 5 dpi (Nelson et al. 1993). Those experiments, however, measured the accumulation of MP fairly late in the infection process of inoculated leaves. In this study, MP accumulation in $\mathrm{M}^{\mathrm{IC}}-$, $\mathrm{U} 1-$, and $\mathrm{M}^{\mathrm{IC}} \mathrm{m} 1-8-$ infected protoplasts was quantitatively similar soon after inoculation (Figs. 4 and 5). Further evidence that the amount of MP is not limiting during $\mathrm{M}^{\mathrm{IC}}$ infections comes from observations that additional MP, derived from U1 and transgenically expressed in $N$. tabacum line 277 , did not alter the mild $\mathrm{M}^{\mathrm{IC}}$ disease symptoms (data not shown) nor the slow accumulation of $\mathrm{M}^{\mathrm{IC}}$ in systemically infected leaves (Table 2). Also, although the accumulation of MP by mutants $\mathrm{M}^{\mathrm{IC}} \mathrm{m} 2, \mathrm{M}^{\mathrm{IC}} \mathrm{m} 4$, and $\mathrm{M}^{\mathrm{IC}} \mathrm{m} 6$ was delayed in Xanthi $\mathrm{nn}$

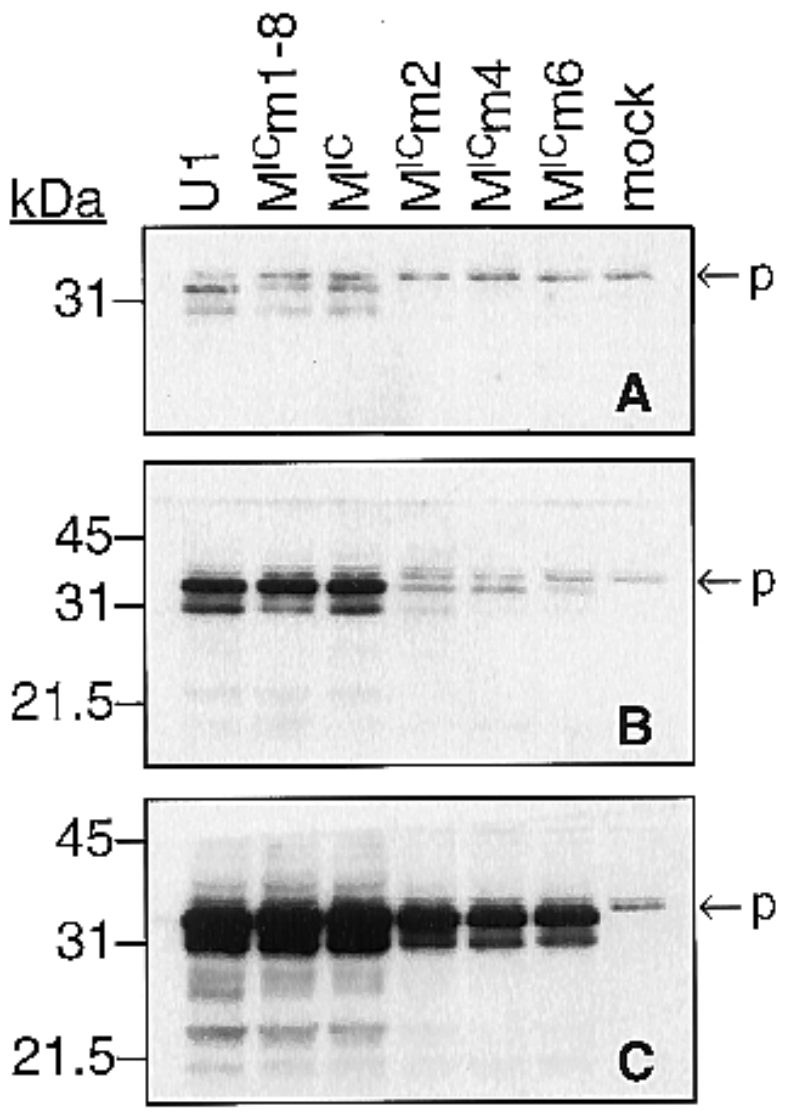

Fig. 5. Immunoblot detection of movement protein in tobacco mosaic virus-infected protoplasts. Protoplasts were inoculated with RNA of U1, $\mathrm{M}^{\mathrm{IC}}$, the mutants shown, or water (mock). Samples equivalent to 15,000 protoplasts were taken at $\mathbf{A}, 3 \mathrm{~h}, \mathbf{B}, 5 \mathrm{~h}$, and $\mathbf{C}, 7 \mathrm{~h}$ postinoculation; proteins were separated by sodium dodecyl sulfate-polyacrylamide gel electrophoresis; and movement protein was revealed by immunoblotting and chemiluminescence detection. $\leftarrow \mathrm{p}$ indicates the position of a plant protein that interacted with movement protein antibody. The positions and sizes of protein standards of known molecular mass are indicated by numbers on the left of the figure. The percentages of protoplasts infected in these experiments were $76 \%(\mathrm{U} 1), 72 \%\left(\mathrm{M}^{\mathrm{IC}}\right), 74 \%\left(\mathrm{M}^{\mathrm{IC}} \mathrm{m} 1-8\right), 58 \%$ $\left(\mathrm{M}^{\mathrm{IC}} \mathrm{m} 6\right), 73 \%\left(\mathrm{M}^{\mathrm{IC}} \mathrm{m} 4\right)$, and $60 \%\left(\mathrm{M}^{\mathrm{IC}} \mathrm{m} 2\right)$. 
protoplasts compared with that of $\mathrm{M}^{\mathrm{IC}}, \mathrm{U} 1$, and $\mathrm{M}^{\mathrm{IC}} \mathrm{m} 1-8$ (Fig. $5)$, these differences did not necessarily lead to decreased phloem-dependent accumulation, since accumulations by $\mathrm{M}^{\mathrm{IC}} \mathrm{m} 2$ and $\mathrm{M}^{\mathrm{IC}} \mathrm{m} 6$ were similar to that of the parental $\mathrm{M}^{\mathrm{IC}}$ in stems (compare results in Figure 5 with those in Figure 2). The MP of $\mathrm{M}^{\mathrm{IC}}$ is also functionally competent, since in the presence of the U1 126- and 183-kDa proteins, it supports U1like symptom production (Holt et al. 1990; Shintaku et al. 1996) and phloem-dependent accumulation $\left(\mathrm{M}^{\mathrm{IC}} \mathrm{m} 1-8\right.$ in Figure 2). Additionally, an $\mathrm{M}^{\mathrm{IC}}-\mathrm{U} 1$ chimeric virus encoding $\mathrm{M}^{\mathrm{IC}}$ proteins, except for a U1 MP, displayed $\mathrm{M}^{\mathrm{IC}}$-like slow phloem-dependent accumulation, indicating that a known functionally competent MP could not alter this phenotype (R. Nelson and S. Carter, unpublished). These results, without exception, indicate that the levels and functional competence of the MP synthesized by $\mathrm{M}^{\mathrm{IC}}$ do not limit the phloem-dependent accumulation of this virus.

Overall, the present and previous data (Holt et al. 1990; Nelson et al. 1993; Ding et al. 1995; Shintaku et al. 1996) indicate that the 126- and/or 183-kDa proteins directly influence phloem-dependent accumulation of TMV in a qualitative manner. Among the viruses we have studied, efficient phloemdependent accumulation and symptom severity map to between amino acids 325 and 747 of the 126- and $183-\mathrm{kDa}$ proteins, but only the symptom phenotype positively correlates with the rate of accumulation of 126- and 183-kDa proteins (compare Figure 1 and Table 1). Results presented in this paper support those of others indicating that replication-associated proteins analogous to the TMV $126-\mathrm{kDa}$ protein from other Sindbis-like viruses also serve as factors influencing phloem-dependent accumulation. Roossinck and Palukaitis (1990) and Gal-On et al. (1994) showed that the rate of phloem-dependent accumulation of cucumber mosaic cucumovirus (CMV) in Cucurbita pepo was determined by the 1a ORF (encoding the analog of the $126-\mathrm{kDa}$ protein). Weiland and Edwards (1994, 1996) similarly mapped phloem-dependent accumulation of barley stripe mosaic virus to the $\alpha$ a gene.

Our results additionally demonstrate that the delay in phloemdependent accumulation of $\mathrm{M}^{\mathrm{IC}}$ and all the site-directed mutants of this virus, except possibly $\mathrm{M}^{\mathrm{IC}} \mathrm{m} 4$, in Xanthi nn was not the result of impaired CP or MP accumulation or function.

Table 2. Virus coat protein accumulation at 7 days postinoculation in inoculated and systemically infected leaves of movement proteinexpressing (MP+) and wild-type (MP-) Xanthi nn

\begin{tabular}{|c|c|c|c|}
\hline \multirow[b]{2}{*}{$\begin{array}{l}\text { Virus } \\
\text { Plant genotype }\end{array}$} & \multicolumn{3}{|c|}{ Virus accumulation $^{y}$} \\
\hline & $\begin{array}{c}\text { Inoculated } \\
\text { leaf }\end{array}$ & $\begin{array}{l}\text { Third } \\
\text { leaf } z\end{array}$ & $\begin{array}{c}\text { Fourth } \\
\text { leaf }^{z}\end{array}$ \\
\hline \multicolumn{4}{|l|}{$\mathrm{M}^{\mathrm{IC}}$} \\
\hline MP+ & $39,700 \mathrm{a}$ & $100 \mathrm{~b}$ & $5 \mathrm{c}$ \\
\hline MP- & $35,000 \mathrm{a}$ & $90 \mathrm{~b}$ & $3 c$ \\
\hline \multicolumn{4}{|l|}{ U1 } \\
\hline MP+ & $43,100 \mathrm{~d}$ & $3,180 \mathrm{e}$ & $780 \mathrm{f}$ \\
\hline MP- & $43,500 \mathrm{~d}$ & $3,840 \mathrm{e}$ & $1,110 \mathrm{f}$ \\
\hline
\end{tabular}

${ }^{\mathrm{y}}$ Values represent the mean coat protein $(\mathrm{CP})$ accumulation (nanograms of tobacco mosaic virus CP per leaf) for three leaves from plants of similar size for each virus-plant combination. Values followed by the same letter were not significantly different when compared by analysis of variance of log-transformed data. Statistical comparisons were between values for MP+ and MP- plants for each virus at each of the three leaf positions.

${ }^{\mathrm{z}}$ Position of the leaf above the inoculated leaf.
Thus, the basis for the masked strain phenotype differs from those suggested for the symptomatically mild TMV $\mathrm{L}_{11} \mathrm{~A}$ strain or for a mutant strain of brome mosaic bromovirus, i.e., that decreased accumulation of MP caused by altered 126and/or 183-kDa protein or 1a protein function result in mild systemic symptoms or delayed systemic accumulation of virus (Oshima et al. 1965; Watanabe et al. 1987; De Jong and Ahlquist 1995). Other researchers have also suggested that altered phloem-dependent accumulation phenotypes for the viruses they studied are not caused by decreased accumulation of MP. Gal-On et al. (1994) observed no differences in 3a (movement) protein accumulation in their CMV strains, which display different rates of phloem-dependent movement. Transgenic expression of TMV MP alone was shown to be insufficient to allow phloem-dependent invasion of $N$. tabacum by red clover mottle virus (RCMV) (Taliansky et al. 1992). Coinoculation of these plants with a TMV mutant possessing a dysfunctional MP allowed phloem-dependent movement of RCMV, suggesting a movement function for a product of the TMV genome other than the MP. Deom et al. (1994) also suggested that a viral factor in addition to the MP was necessary to allow sunn-hemp mosaic tobamovirus to infect $N$. tabacum through phloem movement. All of these studies indicate that viral proteins other than the previously implicated CPs and MPs directly influence phloem-dependent accumulation. Dawson and Hilf (1992) observed that the success or efficiency of systemic viral infection of a plant appears to be determined by the cumulative influence of the efficiencies of replication, cell-to-cell movement, and phloem movement. It is now necessary to determine whether the masked strain phloem-dependent accumulation phenotype is the consequence of structural alterations to the 126- and/or $183-\mathrm{kDa}$ protein that limit their ability to carry out enzymatic or binding functions yet to be detected and assayed or of a 126- and/or 183-kDa protein-induced host response that limits viral protein function.

\section{MATERIALS AND METHODS}

\section{Virus strains and mutants.}

The U1 strain of TMV was as described by Holt et al. (1990). $\mathrm{M}^{\mathrm{IC}}$ and site-directed mutants of $\mathrm{M}^{\mathrm{IC}}$ were those generated as described (Shintaku et al. 1996). Mutants designated $\mathrm{M}^{\mathrm{IC}} \mathrm{m} 2$, $\mathrm{M}^{\mathrm{IC}} \mathrm{m} 4, \quad \mathrm{M}^{\mathrm{IC}} \mathrm{m} 6, \mathrm{M}^{\mathrm{IC}} \mathrm{m} 2,4, \quad \mathrm{M}^{\mathrm{IC}} \mathrm{m} 1,3,6, \mathrm{M}^{\mathrm{IC}} \mathrm{m} 2,4,6, \quad \mathrm{M}^{\mathrm{IC}} \mathrm{m} 1-4$, $\mathrm{M}^{\mathrm{IC}} \mathrm{m} 5-8$, and $\mathrm{M}^{\mathrm{IC}} \mathrm{m} 1-8$ were used in this study (Fig. 1).

\section{Antibodies.}

For use in ELISA and tissue printing, an IgG fraction was purified from antiserum raised against TMV (Ding et al. 1996) by ammonium sulfate precipitation and passage through a Recomb Protein A/G affinity column (Pierce, Rockford, IL) according to the manufacturer's recommendations. Antibody used for immunoblot detection of TMV MP was raised against a synthetic peptide corresponding to a 19-amino acid hydrophilic domain in the U1 MP (Deom et al. 1987) and was kindly provided by C. Michael Deom (University of Georgia, Athens).

\section{Inoculation of $N$. tabacum and analysis of virus accumulation by tissue printing.}

Virus particles were extracted and purified from infected Xanthi nn (systemic host) as described by Asselin and 
Zaitlin (1978). The infectivities of all inocula were tested in each experiment by duplicate inoculation onto half leaves of Xanthi NN (local lesion host); $0.25 \mu \mathrm{g}$ of U1 strain TMV per milliliter was used as a standard on opposite leaf halves, and lesions were counted at 3 or $4 \mathrm{dpi}$.

For the tissue printing experiments, the acropetal half of one 8 - to $11-\mathrm{cm}$-long leaf per young Xanthi nn plant (six to seven leaves longer than $1 \mathrm{~cm}$ ) was manually inoculated with each virus. Plants were maintained in a glasshouse for 3, 4, or 5 dpi. At harvest, stems above the inoculated leaf were cut longitudinally through the vascular trace emerging from the inoculated leaf, and the presence and distribution of TMV CP antigen were revealed by tissue printing. Tissue prints were processed as described by Holt (1992), except that nonfat dried milk was used as the blocking agent.

\section{Inoculation and analysis of virus accumulation in transgenic tobacco expressing MP.}

Seeds of transgenic Xanthi nn that express TMV U1 strain MP (line 277) were obtained from C. Michael Deom and Roger Beachy (Scripps Research Institute, La Jolla, CA). Xanthi nn and line 277 plants were paired by approximating their plastochron indices (Erickson and Michelini 1957) and inoculated with purified virus as described above. Inoculum concentrations were $6.3 \mu \mathrm{g} / \mathrm{ml}$ for $\mathrm{M}^{\mathrm{IC}}$ and $5.5 \mu \mathrm{g} / \mathrm{ml}$ for $\mathrm{U} 1$. The first leaf greater than $4 \mathrm{~cm}$ in midrib length and the leaf below it were inoculated with 20 and $40 \mu \mathrm{l}$, respectively. Inoculated and systemically infected leaves were harvested at $7 \mathrm{dpi}$, frozen in liquid nitrogen, and stored at $-70^{\circ} \mathrm{C}$. Leaf tissue was powdered with a mortar and pestle with liquid nitrogen. Phosphate-buffered saline (PBS) was added (Nelson et al. 1993), and the extract was centrifuged (10 min at 10,000 $\times g$ ). CP accumulation in the supernatant was assayed by ELISA as described by Clark and Adams (1977).

Preparation, inoculation, and manipulation of protoplasts.

Preparations enriched in palisade mesophyll protoplasts were prepared essentially as described by Kubo and Takanami (1979) from leaves of Xanthi nn plants maintained in a growth chamber at $24^{\circ} \mathrm{C}$ with a 16 -h day length providing a photon fluence rate of $100 \mu \mathrm{mol} \mathrm{m} \mathrm{s}^{-2}$ at pot level. For inoculation, pelleted protoplasts $\left(10^{6}\right.$ per treatment) were mixed with $5 \mu \mathrm{g}$ of TMV RNA, which was isolated from purified virus particles as described (Bruening et al. 1976). The mixture was then swirled with $0.5 \mathrm{ml}$ of a $40 \%$ polyethylene glycol (molecular weight 1540) (Polysciences Inc., Warrington, PA) solution containing $3.0 \mathrm{mM} \mathrm{CaCl}_{2}$ and $3.0 \mathrm{mM}$ 2-( $N$-morpholino)ethanesulphonic acid, $\mathrm{pH} 5.5$, for approximately $15 \mathrm{~s}$ followed by dilution with $5.0 \mathrm{ml}$ of $0.7 \mathrm{M}$ mannitol containing $3.0 \mathrm{mM}$ $\mathrm{CaCl}_{2}$ and incubation on ice for $15 \mathrm{~min}$. Protoplasts were washed three times with $0.7 \mathrm{M}$ mannitol containing $3.0 \mathrm{mM}$ $\mathrm{CaCl}_{2}$ and incubated at $24^{\circ} \mathrm{C}$ with constant illumination at a photon fluence rate of $10 \mu \mathrm{mol} \mathrm{m} \mathrm{m}^{-2} \mathrm{~s}^{-1}$ in $3.0 \mathrm{ml}$ of the medium described by Otsuki et al. (1972) containing $100 \mu \mathrm{g}$ of carbenicillin per milliliter per $10^{6}$ protoplasts inoculated.

For ELISA, samples were centrifuged, and the pellet was frozen and stored at $-20^{\circ} \mathrm{C}$ until needed. Before assay, pellets were vortex mixed with $100 \mu \mathrm{l}$ of PBS, sonicated for $10 \mathrm{~min}$, refrozen, and thawed. The protein content of extracts was assayed by using a commercial dye reagent (Bio-Rad, Richmond, CA). Virus CP in centrifuged samples containing the equivalent of 10,000 protoplasts was assayed by ELISA. The proportion of infected protoplasts was assessed for each inoculation at $30 \mathrm{~h}$ postinoculation by indirect immunofluorescence staining; at least 400 protoplasts were scored per sample.

The presence of the original mutations in each virus was verified by sequencing products of reverse transcription and polymerase chain reaction amplification of viral RNA extracted from protoplasts sampled at $42 \mathrm{~h}$ postinoculation as described in Shintaku et al. (1996).

For radiolabeling of viral proteins, protoplasts were prepared as above, but with cellulase digestion at $24^{\circ} \mathrm{C}$ for 60 to $75 \mathrm{~min}$. Protoplasts were inoculated and incubated as described above, except that the incubation medium was supplemented with $80 \mu \mathrm{g}$ of actinomycin D per $\mu \mathrm{l}$. At 8 and $15 \mathrm{~h}$ postinoculation, aliquots containing $2 \times 10^{5}$ protoplasts in 0.5 $\mathrm{ml}$ were incubated with $5.0 \mu \mathrm{Ci}$ of a mixture of ${ }^{35}[\mathrm{~S}]$-methionine and ${ }^{35}[\mathrm{~S}]$-cysteine (NEN, Boston, MA) for $2 \mathrm{~h}$ at $24^{\circ} \mathrm{C}$. Protoplasts were collected by centrifugation, and ${ }^{35} \mathrm{~S}$-labeled proteins were separated by SDS-PAGE in $11 \%$ gels (Laemmli 1970). Dried gels were analyzed with a PhosphorImager and ImageQuant software (Molecular Dynamics, Sunnyvale, CA). The remaining protoplasts were cultured until $48 \mathrm{~h}$ postinoculation and then assessed for the percentage of infection as described above.

For immunoblot detection of MP accumulation in protoplasts, samples equivalent to 15,000 protoplasts were harvested by centrifugation at intervals up to $7 \mathrm{~h}$ postinoculation, immediately frozen, and stored at $-70^{\circ} \mathrm{C}$. Frozen pellets were dispersed by vortex mixing with $10.0 \mu \mathrm{l}$ of gel loading buffer (125 mM Tris, 4\% SDS, $200 \mathrm{mM}$ dithiothreitol, 20\% glycerol, and $0.02 \%$ bromophenol blue, $\mathrm{pH} 6.8$ ) and heated on a boiling water bath for $10 \mathrm{~min}$. Proteins were separated by SDS-PAGE in $14 \%$ gels and transferred to nitrocellulose sheets (Bio-Rad) by electroelution. MP was detected via alkaline phosphataseconjugated secondary antibody and 3-(4-methoxyspiro(1,2dioxetane-3,2'-(5'-chloro)tricyclo(3.3.1.1 $\left.{ }^{3,7}\right)$ decan)-4-yl)phenyl phosphate (CSPD) chemiluminescence substrate (Western Light chemiluminescence detection kit, Tropix, Bedford, MA). Images were recorded on X-Omat AR film (EastmanKodak, Rochester, NY).

\section{ACKNOWLEDGMENTS}

We thank C. Michael Deom for kindly providing antibodies against movement protein and transgenic tobacco seed. We also thank Roger Beachy for transgenic tobacco seed and suggestions on experiments. Maria Harrison and Stanislaw Flasinski are thanked for comments during preparation of the manuscript, Bob Gonzales and Valerie Graves for DNA sequencing, Evan Burrows and Cuc Ly for preparing figures, and Allyson Wilkins for typing the manuscript.

\section{LITERATURE CITED}

Asselin, A., and Zaitlin, M. 1978. Characterization of a second protein associated with virions of tobacco mosaic virus. Virology 91:173-181.

Bao, Y., Carter, S. A., and Nelson, R. S. 1996. The 126- and 183-kilodalton proteins of tobacco mosaic virus, and not their common nucleotide sequence, control mosaic symptom formation in tobacco. J. Virol. 70:6378-6383.

Bruening, G., Beachy, R. N., Scalla, R., and Zaitlin, M. 1976. In vitro and in vivo translation of the ribonucleic acids of a cowpea strain of tobacco mosaic virus. Virology 71:498-517.

Carrington, J. C., Kasschau, K. D., Mahajan, S. K., and Schaad, M. C. 
1996. Cell-to-cell and long-distance transport of viruses in plants. Plant Cell 8:1669-1681.

Clark, M. F., and Adams, A. N. 1977. Characteristics of the microplate method of enzyme-linked immunosorbent assay for the detection of plant viruses. J. Gen. Virol. 34:475-483.

Dawson, W. O., and Hilf, M. E. 1992. Host-range determinants of plant viruses. Annu. Rev. Plant Physiol. Plant Mol. Biol. 43:527-555.

De Jong, W., and Ahlquist, P. 1995. Host-specific alterations in viral RNA accumulation and infection spread in a brome mosaic virus isolate with an expanded host range. J. Virol. 69:1485-1492.

Deom, C. M., Oliver, M. J., and Beachy, R. N. 1987. The 30-kilodalton gene product of tobacco mosaic virus potentiates virus movement. Science 237:389-394.

Deom, C. M., He, X. Z., Beachy, R. N., and Weissinger, A. K. 1994. Influence of heterologous tobamovirus movement protein and chimericmovement protein genes on cell-to-cell and long-distance movement. Virology 205:198-209.

Ding, X. S., Shintaku, M. H., Arnold, S. A., and Nelson, R. S. 1995. Accumulation of mild and severe strains of tobacco mosaic virus in minor veins of tobacco. Mol. Plant-Microbe Interact. 8:32-40.

Ding, X. S., Shintaku, M. H., Carter, S. A., and Nelson, R. S. 1996 Invasion of minor veins of tobacco leaves inoculated with tobacco mosaic virus mutants defective in phloem-dependent movement. Proc. Natl. Acad. Sci. USA 93:11155-11160.

Dunigan, D. D., and Zaitlin, M. 1990. Capping of tobacco mosaic virus RNA: Analysis of viral-coded guanylyltransferase-like activity. J. Biol. Chem. 265:7779-7786.

Erickson, R. O., and Michelini, F. J. 1957. The plastochron index. Am. J. Bot. 44:297-305.

Evans, R. K., Haley, B. E., and Roth, D. A. 1985. Photoaffinity labeling of a viral induced protein from tobacco: Characterization of nucleotide-binding properties. J. Biol. Chem. 260:7800-7804.

Fenczik, C. A., Padgett, H. S., Holt, C. A., Casper, S. J., and Beachy, R. N. 1995. Mutational analysis of the movement protein of Odontoglossum ringspot virus to identify a host-range determinant. Mol. PlantMicrobe Interact. 8:666-673.

Gal-On, A., Kaplan, I., Roossinck, M. J., and Palukaitis, P. 1994. The kinetics of infection of zucchini squash by cucumber mosaic virus indicate a function for RNA 1 in virus movement. Virology 205:280289.

Gilbertson, R. L., and Lucas, W. J. 1996. How do viruses traffic on the 'vascular highway'? Trends Plant Sci. 1:260-267.

Goelet, P., Lomonossoff, G. P., Butler, P. J. G., Akam, M. E., Gait, M. J., and Karn, J. 1982. Nucleotide sequence of tobacco mosaic virus RNA. Proc. Natl. Acad. Sci. USA 79:5818-5822.

Gorbalenya, A. E., and Koonin, E. V. 1989. Viral proteins containing the purine NTP-binding sequence pattern. Nucleic Acids Res. 17:84138440.

Goulden, M. G., and Baulcombe, D. C. 1993. Functionally homologous host components recognize potato virus X in Gomphrena globosa and potato. Plant Cell 5:921-930.

Holmes, F. O. 1934. A masked strain of tobacco mosaic virus. Phytopathology 24:845-873.

Holt, C. 1992. Detection and localization of plant pathogens. Pages 125 137 in: Tissue Printing: Tools for the Study of Anatomy, Histochemistry and Gene Expression. P. D. Reid and R. F. Pont-Lezica, eds. Academic Press, San Diego, CA.

Holt, C. A., Hodgson, R. A. J., Coker, F. A., Beachy, R. N., and Nelson, R. S. 1990. Characterization of the masked strain of tobacco mosaic virus: Identification of the region responsible for symptom attenuation by analysis of an infectious cDNA clone. Mol. Plant-Microbe Interact. 3:417-423.

Ishikawa, M., Meshi, T., Motoyoshi, F., Takamatsu, N., and Okada, Y. 1986. In vitro mutagenesis of the putative replicase genes of tobacco mosaic virus. Nucleic Acids Res. 14:8291-8305.

Ishikawa, M., Meshi, T., Ohno, T., and Okada, Y. 1991. Specific cessation of minus-strand RNA accumulation at an early stage of tobacco mosaic virus infection. J. Virol. 65:861-868.

Köhm, B. A., Goulden, M. G., Gilbert, J. E., Kavanagh, T. A., and Baulcombe, D. C. 1993. A potato virus X resistance gene mediates an induced, nonspecific resistance in protoplasts. Plant Cell 5:913-920.

Kubo, S., and Takanami, Y. 1979. Infection of tobacco mesophyll protoplasts with tobacco necrotic dwarf virus, a phloem-limited virus. J. Gen. Virol. 42:387-398.

Laemmli, E. K. 1970. Cleavage of structural proteins during the assembly of the head of bacteriophage T4. Nature 227:680-685.

Nelson, R. S., Li, G., Hodgson, R. A. J., Beachy, R. N., and Shintaku, M. H. 1993. Impeded phloem-dependent accumulation of the masked strain of tobacco mosaic virus. Mol. Plant-Microbe Interact. 6:45-54.

Oshima, N., Komochi, S., and Goto, T. 1965. Study on control of plant virus diseases by vaccination of attenuated virus. I. Control of tomato mosaic disease. Pages 23-33 in: Hokkaido Natl. Agric. Exp. Stn. Res. Bull. 85.

Otsuki, Y., Shinomura, T., and Takebe, I. 1972. Tobacco mosaic virus multiplication and expression of the $\mathrm{N}$ gene in necrotic responding tobacco leaves. Virology 50:45-50.

Roossinck, M. J., and Palukaitis, P. 1990. Rapid induction and severity of symptoms in zucchini squash (Cucurbita pepo) map to RNA 1 of cucumber mosaic virus. Mol. Plant-Microbe Interact. 3:188-192.

Rozanov, M. N., Koonin, E. V., and Gorbalenya, A. E. 1992. Conservation of the putative methyltransferase domain: A hallmark of the 'Sindbis-like' supergroup of positive-strand RNA viruses. J. Gen. Virol. 73:2129-2134

Scholthof, H. B., Morris, T. J., and Jackson, A. O. 1993. The capsid protein gene of tomato bushy stunt virus is dispensable for systemic movement and can be replaced for localized expression of foreign genes. Mol. Plant-Microbe Interact. 6:309-322.

Séron, K., and Haenni, A.-L. 1996. Vascular movement of plant viruses. Mol. Plant-Microbe Interact. 9:435-442.

Shintaku, M. H., Carter, S. A., Bao, Y., and Nelson, R. S. 1996. Mapping nucleotides in the $126-\mathrm{kDa}$ protein gene that control the differential symptoms induced by two strains of tobacco mosaic virus. Virology 221:218-225.

Taliansky, M. E., Malyshenko, S. I., Kaplan, I. B., Kondakova, O. A., and Atabekov, J. G. 1992. Production of the tobacco mosaic virus (TMV) transport protein in transgenic plants is essential but insufficient for complementing foreign virus transport: A need for the fulllength TMV genome or some other TMV-encoded product. J. Gen. Virol. 73:471-474.

Watanabe, Y., Morita, N., Nishiguchi, M., and Okada, Y. 1987. Attenuated strains of tobacco mosaic virus reduced synthesis of a viral protein with a cell-to-cell movement function. J. Mol. Biol. 194:699-704.

Weiland, J. J., and Edwards, M. C. 1994. Evidence that the $\alpha$ a gene of barley stripe mosaic virus encodes determinants of pathogenicity to oat (Avena sativa). Virology 201:116-126.

Weiland, J. J., and Edwards, M. C. 1996. A single nucleotide substitution in the $\alpha$ a gene confers oat pathogenicity to barley stripe mosaic virus strain ND18. Mol. Plant-Microbe Interact. 9:62-67. 